\title{
Board Size, Board Composition and Performance: An Investigation on Turkish Banks
}

\author{
Ozcan $\operatorname{ISIK}^{1} \&$ Ali Riza INCE ${ }^{2}$ \\ ${ }^{1}$ Department of Banking and Finance, School of Applied Sciences, Cumhuriyet University, Sivas, Turkey \\ ${ }^{2}$ Department of Management Information Systems, Faculty of Economics and Administrative Sciences, \\ Cumhuriyet University, Sivas, Turkey \\ Correspondence: Ozcan ISIK, Department of Banking and Finance, School of Applied Sciences, Cumhuriyet \\ University, Sivas, Turkey. Tel: 90-532-650-1298. E-mail: ozcan@live.com
}

Received: December 12, 2015

Accepted: January 7, 2016

Online Published: January 25, 2016

doi: 10.5539/ibr.v9n2p74

URL: http://dx.doi.org/10.5539/ibr.v9n2p74

\begin{abstract}
We investigate the impact of board size and board composition on performance for a sample of 30 commercial banks from 2008 to 2012 in Turkey. We measure bank performance by two alternative measures widely used in the banking literature, i.e. operating return on assets (OROA) and return on assets (ROA). Controlling for bank size, credit risk, liquidity risk, net interest margin and non-interest income, the results of panel fixed effects regression suggest that board size has a significantly positive effect on bank's financial performance. This means that Turkish commercial banks may improve their financial performance by increasing their board size. Our findings, however, show clearly that there is no significant relationship between board composition (ratio of outside directors on the board) and banks' financial performance.
\end{abstract}

Keywords: bank performance, board size, board composition, corporate governance

\section{Introduction}

In this study, we examine the relationship between board size, percentage of outside directors and performance in the Turkish banking sector. The influence of board size and composition on performance has attracted the interests of many researchers. Industrial firms are generally at the focus of attention in studies investigating the relationship between board structure and performance. The number of studies on the relationship of board structure and performance of financial firms, especially banks, is limited. But, how banks are governed and the board structure of them may affect their performance in some way and even lead to outstanding performance or, on the contrary, corporate failure. Along with many other factors, the bad governance of financial firms has caused the global financial crisis which started in 2007-2008. Therefore, as an integral part of bank governance the board structure and its impact on bank performance is worth investigating.

The board of directors makes decisions that are essential to the firm's performance. It is regarded as an integral part of internal governance mechanisms through which decisions and actions of managers can be monitored (Fama, 1980). The board of directors can be considered a control device that limits agency problems between top management and shareholders (Hermalin \& Weisbach, 1991). A well governed firm is expected to have better performance and the rational decisions of the board of directors make an important contribution to the governance. Therefore, it is highly likely that the structure of the board of directors affects firm performance.

Special nature and characteristics of banks make governance of them more different than other firms. The difference of bank balance sheets from those of non-bank firms (banks are highly leveraged), the mismatch in the term structure and liquidity of their assets and liabilities, deposit insurance funds' insurance provided to depositors encouraging bank managers and shareholders to take on excessive risk, more pronounced conflicts between the interests of lenders and shareholders due to high debt to equity ratio of banks, the possibility of reduced incentives for monitoring due to the presence of deposit insurance make the board of directors, as a governance mechanism, in a bank more important than non-bank firms (Macey \& O'Hara, 2003).

The board size is one of board characteristics that we use in this study. The majority of studies in the literature suggest negative association between board size and firm performance. Board size is negatively related to firm value due to the fact that firms with larger board of directors tend to use their assets less efficiently and earn less 
profit (Yermack, 1996). For example, Jensen (1993) suggests that a limited number of board members are important for effective corporate governance. Hermalin and Weisbach (2003) reported that board size is negatively associated with firms'financial performance and the quality of decision-making. Mak and Kusnadi (2005) find that board size has a negative impact on firm value in Singapore and Malaysia. Using a large sample of UK listed firms and controlling for different types of endogeneity, Guest (2009) finds that board size has a strong negative effect on firm profitability measured by Tobin's Q and stock returns. O'Connell and Cramer (2010) reveal a negative association between board size and performance of firm, measured by ROA and financial Q for firms listed on the Irish Stock Market. Based on a sample of Canadian service firms listed on Toronto Stock Exchange, Gill and Mathur (2011) uncover a negative relation between board size and firm profitability. Nguyen et al. (2014) investigate a sample of 257 Singaporean non-financial listed firms for the period of 2008 to 2011. They conclude that the board size has a significantly negative influence on firm performance after controlling for endogeneity issue. Conversely, based on samples of non-financial firms, Boone et al. (2008), Coles et al. (2008), Linck et al. (2008) and Lehn et al. (2009) conclude that some firms may benefit from large board of directors.

Outside board directors is another board characteristic that we investigate for a possible relation with bank performance. Independent outside directors who do not have relationships or common interests with management, are considered to monitor the management more effectively (Hermalin \& Weisbach, 2003). The CEO can affect inside board directors relatively more than he/she can affect outside independent directors. Therefore a high percentage of independent directors on the board may affect the performance of firms positively. On the other hand, the high representation of independent directors on the board may be negatively associated with performance. Within this respect, findings on the relation between the independence of the board and firm performance are mixed.

Agrawal and Knoeber (1996), Yermack (1996) and Bhagat and Black (1999) report a negative relation between the proportion of independent directors on the boards and Tobin's Q. Guest (2009) concludes that the number of outside directors on the board is negatively related to profitability measures, Tobin's Q and stock return. On the other hand, studies that find a positive relation between the percentage of outside independent directors on the board and firm performance are prevalent. Based on a final sample of 526 firms, Schellenger et al. (1989) find that the percentage of outside directors on the board is positively related to risk-adjusted shareholder's annualized total market return on investment (RET/STD) and return on assets (ROA). Borokhovich et al. (1996) provide support that a positive relation between appointments of outside CEOs and stock returns when the existing CEO is forced to leave the firm. O'Connell and Cramer (2010) report that there is a positive and significant relationship between the percentage of non-executive directors on the board and performance, measured by ROA and RET (stock market return adjusted for dividends) for firms listed on the Irish Stock Market.

There are also studies finding no or uniform relations between the independence of the board of directors and firm performance. Baysinger and Butler (1985) conclude that the percentage of outside independent directors has a mild but lagged effect on firm performance. Their results suggest that increase in firm performance decreases as a response to additions of independent directors to the board. Schellenger et al. (1989) document that the percentage of outside directors on the board is not associated with RET (shareholder's annualized total market return on investment) and ROE (return on equity). Hermalin and Weisbach (1991) and Bhagat and Black (2001) report no relationship between the percentage of outside directors on the board and performance.

Board structure consists of a wide range of elements, like board size, outside board members, independence of board members, CEO-duality, board member ownership, nationality, gender, and education level of members. In this study we investigate the relation between some board characteristics and performance of Turkish commercial banks measured by operating return on assets (OROA) and return on assets (ROA). In our regression models we use board size and the ratio of the number of outside (non-executive) directors to the total number of directors on the board as representatives of board characteristics. Along with these board variables, we also employ bank size (TA), credit risk (CR), liquidity risk (LR), net interest margin (NIM) and non-interest income (NII) as bank specific variables.

This study contributes empirical evidence to the little studied area of corporate governance issues in commercial banks in the Turkish context. To best of our knowledge, there are several previous banking studies (e.g., Kaymak \& Bektas, 2008; Bektas \& Kaymak, 2009; Aygün et al., 2010 and Doğan \& Yıldız, 2013) investigating the board structure-performance relationship in Turkey. Our study differs from theirs in the way we use panel data methodologies, i.e., fixed-effects regressions with bank and year fixed effects. In other words, we re-investigate the causal effect of board structure on bank performance using fixed-effects (within group) estimator to control 
for the unobserved bank specific effects. The empirical results indicate that Turkish commercial banks may improve their performance by increasing their board size.

The rest of the paper is organized as follows. Section 2 presents previous studies and then develops our hypotheses. Section 3 provides data, variables and methodology. Empirical findings are presented in section 4. Section 5 completes the paper with concluding remarks.

\section{Literature Review and Hypotheses Development}

In spite of the fact that there are lots of theories explaining whether boards may have an influence on firms financial performance, this study benefits from agency theory and resource dependence theory most often employed by researchers in finance and economics in order to understand the relationship between board structure and firm financial performance. Each of these perspectives addresses different aspects of the roles of board members. While agency theory underlines the role of board members to monitor management in order to resolve agency problems between managers and shareholders (Fama \& Jensen, 1983), resource dependence theory emphasizes that main role of board members is primarily to provide access to valuable external resources (Pfeffer \& Salancik, 1978). In this section, we employ previous research findings as well as theory to develop and test our hypotheses for Turkish banking sector.

\subsection{Board Size and Bank Performance}

It is widely recognized that the board size is a crucial internal mechanism of corporate governance and plays a major role in firm's management. For this reason, board size and its impact on firm financial performance is one of the most argued issues in corporate governance. The agency theory contends that superior firm financial performance may be associated with smaller board size. Compared to larger boards, smaller boards are less likely to have difficulty in coordinating and communicating. Furthermore, a smaller board is probably more effective at monitoring management's activities because it cannot be easily influenced by the CEO and thus smaller board size may cause better firm financial performance, (Lipton \& Lorsch, 1992; Jensen, 1993). This view strongly stresses the importance of smaller boards, whereas resource dependence approach is in favor of large boards. From the viewpoint of the resource dependence theory, it is argued that boards with a large number of directors may be advantageous in reducing dependency on external resources because larger boards may provide greater opportunity for more environmental linkages than smaller boards (Pfeffer \& Salancik, 1978; Goodstein et al., 1994; Dalton et al., 1999; Ruigrok et al., 2006).

Using a sample of 58 large European banks over the period 2002-2004, Panagiotis et al. (2007) uncover a negative relation between the size of board of directors and profitability. Based on a sample of 57 large European commercial banks operating in the EU-12 countries for the period of 2002-2006, Agoraki et al. (2009) find a negative relation between board size and bank performance measured by cost and profit efficiency. Their findings suggest that banks with smaller boards are more efficient. Using data of US bank holding companies for the period of 1997-2011, Pathan and Faff (2013) report that board size is negatively related to bank performance. Liang et al. (2013) investigate the effects of board characteristics such as size, composition and functioning of the board of directors on financial performance of banks and asset quality, using a sample of 50 Chinese commercial banks over the period 2003-2010. Their findings suggest that board size has a significant and negative effect on bank performance measured by ROA and ROE. Based on data of US banking organizations during the period 1995-2002, Belkhir (2009) examines the relation between board size and performance. He finds that board size and performance, measured by Tobin's Q and ROA are positively related. Using 34 years of data Adams and Mehran (2012) analyze the relationship between board governance and performance using a sample of large bank holding companies in the US over a period of 1986-1999. They find a positive relationship between board size and performance, as measured by a proxy for Tobin's Q. Coles et al. (2008) find a U-shaped relation between Tobin's $Q$ and board size, suggesting that either very small or very large boards are optimal. They attribute this relation to differences between complex and simple firms. They find a positive effect of board size on Tobin's Q for complex firms and a negative one for simple firms. Andres and Vallelado (2008) employ a sample of 69 large commercial banks from six developed countries (Canada, France, Italy, Spain, the UK, and the US), and find an inverted U-shaped relationship between bank performance and size of board of directors. Adding new members to the board is found to increase bank performance measured by Tobin's Q, but to decrease when the size of the board is 19 and more. For the Turkish market, Kaymak and Bektas (2008) and Bektas and Kaymak (2009) uncover no relation between board size and bank performance. Aygün et al. (2010) and Doğan and Yildız (2013) investigate the effect of board size on bank performance for the period of 2006-2008 and 2005-2010, respectively. Using data of 12 banks traded on BIST, their findings suggest that board size is significantly negatively correlated with bank profitability. Given the smaller size of Turkish bank boards, 
we propose the following hypothesis for Turkish banks:

Hypothesis 1: Board size is positively correlated with bank performance

\subsection{Outside Directors and Bank Performance}

Agency theory maintains that the existence of outside directors (non-executive) on board enable the board to better monitor any self-interested actions by managers and reduce agency problems (van der Walt \& Ingley, 2003; Nicholson \& Kiel, 2007). In accordance with this perspective, appointing more outside directors provides greater independence to the board and a greater presence of outside board members on the board may improve board effectiveness and firm financial performance (Fama \& Jensen, 1983). From the resource dependence perspective, it is contended that outside directors play important roles in providing access to necessary resources from the external environment (Pfeffer \& Salancik, 1978). Both agency and resource dependence theory predict that increasing proportion of outside directors on the board may ultimately lead to improvements in firm financial performance. Board independence expressed as the ratio of the number of outside (non-executive) directors to the total number of directors on the board is a common definition used in the academic literature. Findings on the relation between board independence and bank performance in the literature are not conclusive. Choi and Hasan (2005) investigate the impact of ownership and governance on bank performance using data for Korean commercial banks for the period 1998-2000. The paper analyzes how the presence of outside directors, especially foreign directors, on the board of directors affects bank performance. The findings imply no significant relation between bank performance and the number of outside directors on the board. Simpson and Gleason, (1999) examine the relation between ownership structure of board of directors and bank failures and find that the percentage of insiders on the board is not significantly related to the probability of financial distress. Adams and Mehran (2012) analyze the relationship between board governance and performance using a sample of large bank holding companies and find no relationship between board independence and performance, as measured by a proxy for Tobin's Q. Using data of the largest publicly traded bank holding companies in the United States over 1994-2002 period, Cornett et al. (2009) examine the influence of corporate governance mechanisms on earnings and earnings management. As far as board independence is concerned board independence is found to affect earnings represented by earnings before extraordinary items and after taxes to total assets positively. For 50 largest Chinese banks, Liang et al. (2013) examine whether the effect of board characteristics on bank performance for the period of 2003-2010. They uncover a positive relationship between the percentage of independent directors and bank performance measured by ROA and ROE. Using data on Thai commercial banks over the period 1999-2003, Pathan et al. (2007) find a positive significant relationship between the percentage of independent directors and ROE as a bank performance measure. On the other hand, Pathan and Faff (2013) find that the percentage of independent directors is negatively related to bank performance for US bank holding companies over the period 1997-2011. Based on a sample of 57 large European commercial banks operating in the EU-12 countries over the period 2002-2006, Agoraki et al. (2009) find that the number of non-executive directors on the board is negatively related to banks' profit efficiency beyond a certain point. For 69 large commercial banks from six developed countries such as the UK, the US, France, Canada, Italy and Spain, Andres and Vallelado (2008) find an inverted U-shaped relation between the percentage of non-executive directors on the board and bank performance. Within the Turkish context, Kaymak and Bektas (2008) find that the proportion of outside directors is uncorrelated with bank performance measured by ROA, whereas Bektas and Kaymak (2009) report mixed results regarding outside directors-performance relationship when adding the quadratic and cubic form of the proportion of outside board members to their basic models. Based on existing theories and mixed results on proportion of outside directors, we propose the following hypothesis for Turkish banks:

Hypothesis 2: The proportion of outside directors is uncorrelated with bank performance.

\section{Data and Empirical Model}

\subsection{Sample}

Sample used is an unbalanced panel dataset of 30 commercial banks operating in Turkey over the period 2008-2012. While financial data on banks is mainly obtained from the web page of the Bank Association of Turkey (BAT), the detailed information on board size and outside directors is hand-collected from the annual reports of individual banks.

\subsection{Variables}

\subsubsection{Bank Performance Variables}

We measure bank performance by two alternative measures widely used in the banking studies. Our first 
performance variable, operating return on assets (OROA), is defined as pre-tax operating income divided by total assets. Our second performance variable, return on assets (ROA), indicates net income over total assets (Note 1).

\subsubsection{Board Structure Variables}

Following the earlier literature on the relationship between board structure and financial performance, we use two measures of board structure i.e., board size (BS) and board composition (BC). BS is total number of inside and outside directors on the board of the directors. BC is measured by the proportion of the number of outside (non-executive) directors to the board size. We define the inside directors on the board of directors as general manager and vice general manager, and then we subtract them from all of the board members to determine who the outsiders are (Kaymak \& Bektas, 2009). In this way, the measure of BC is simply generated by dividing outside board members by all of the board members. Our outside director's definition does not mean that outsiders are independent board members. We cannot use independent directors as a measure of board structure because of the fact that there is no clear information about independent board members on annuls reports of Turkish commercial banks for the period of 2008-2012.

\subsubsection{Control Variables}

In line with previous studies (e.g., Pathan et al., 2007; Kaymak \& Bektas, 2009; Adams \& Mehran, 2012; Liang et al. 2013), we also use bank specific variables such as total assets (Ln (TA)), credit risk (CR), liquidity risk (LR) (Note 2), net interest margin (NIM) and non-interest income (NII). Finally, the dummy variables for each year are included in our models to control for year effects. The definitions and descriptive statistics for the variables used to investigate the relationship between board structure and performance in banking sector are presented in Table 1 and Table 2, respectively.

Table 1. Definition of variables used in this study

\begin{tabular}{|c|c|c|}
\hline Variables & Notation & Description \\
\hline \multicolumn{3}{|c|}{ Panel A: Bank performance variables } \\
\hline Operating return on assets & OROA & The ratio of pre-tax operating income to total assets \\
\hline Return on assets & ROA & The ratio of net income to total assets \\
\hline \multicolumn{3}{|c|}{ Panel B: Board structure variables } \\
\hline Board size & BS & Total number of inside and outside directors on the board. \\
\hline Board composition & $\mathrm{BC}$ & $\begin{array}{l}\text { The ratio of the number of outside (non-executive) directors to total number } \\
\text { of directors on the board }\end{array}$ \\
\hline \multicolumn{3}{|l|}{ Panel C: Control variables } \\
\hline Bank size & $\operatorname{Ln}(\mathrm{TA})$ & The natural logarithm of banks' total assets \\
\hline Credit risk & $\mathrm{CR}$ & The ratio of non-performing loan to gross loans \\
\hline Liquidity risk & LR & $\begin{array}{l}\text { The ratio of financial gap to total assets } \\
\text { Financial gap is difference between the loans and the customer's deposits. }\end{array}$ \\
\hline Net interest margin & NIM & The ratio of net interest income to total assets \\
\hline Non-interest income & NII & The ratio of non-interest income to total assets \\
\hline
\end{tabular}

\subsection{Empirical Model}

The following fixed-effects model which is similar to that of Pathan et al. (2007), Belkhir (2009) and Adams and Mehran (2012) is employed to investigate the relationship analysis of bank board size, composition and performance:

$$
\text { Performance }_{i t}=\alpha+\beta_{1} \mathrm{BS}_{\mathrm{it}-1}+\beta_{2} \mathrm{BC}_{\mathrm{it}-1}+\beta_{3} \mathrm{X}_{\mathrm{it}-1}+\zeta \lambda_{\mathrm{t}}+\xi \mu_{\mathrm{i}}+\epsilon_{\mathrm{it}}
$$

Where performance, is either OROA or ROA of bank $\mathrm{i}$ in year $\mathrm{t}$; $\alpha$ is a constant term; BS and BC represent board size and board composition, respectively; a vector of bank specific variables $\mathrm{X}$ represents control variables such as size (Ln(TA)), credit risk (CR), liquidity risk (LR), net interest margin (NIM) and non-interest income (NII). The vector $\lambda$ contains year dummies, $\mu$ is a vector of the unobserved bank-specific effects; and $\epsilon_{i t}$ is a white-noise error term. All independent and control variables are lagged by one year to reduce potential endogeneity problems. The coefficients $\alpha, \beta_{1}, \beta_{2}, \beta_{3}$ are the parameters to be estimated. 


\section{Results}

\subsection{Descriptive Statistics for the Variables}

Table 2 presents the results of descriptive statistics for the variables over the period 2008 to 2012. The descriptive statistics of performance variables is presented in Panel A of Table 2. The mean of OROA and ROA of our sample banks are 0.0228 (median, 0.0199 ) and 0.0182 (median, 0.0160 ), respectively. The differences in mean and median values of performance variables suggest that performance differences among our sample banks are important. As far as board variables are concerned, Panel B of Table 2 reports the descriptive statistics for board variables. The average BS of the sample Turkish banks is 8.14 (median, 9), which is relatively lower when compared to those reported by Pathan et al. (2007) for Thai banks, Andres and Vallelado (2008) for six OECD countries (the US, the UK, Canada, Spain, France and Italy), Tanna et al. (2011) for U.K. banks, Adams and Mehran (2012) and Pathan and Faff (2013) for U.S. banks. The average value of BC on bank boards in Turkey is 0.8278 (median, 0.8888).

Finally, summary statistics of our control variables are provided in Panel C of Table 2. The mean of TA is equal to 32.021 (median, 4.683) billion Turkish liras. TA has quite positively skewed distribution. Therefore, the distribution of TA is normalized by using its natural logarithm in the regression models. While the mean of CR and LR are 0.0546 (median, 0.0354) and -0.0781 (median, -0.0469), the mean of NIM and NII are respectively about 0.0544 (median, 0.0479 ) and 0.0184 (median, 0.0167), respectively.

Table 2. Descriptive statistics

\begin{tabular}{|c|c|c|c|c|c|c|}
\hline Variable & Mean & Median & SD & Min & Max & $\mathbf{N}$ \\
\hline \multicolumn{7}{|c|}{ Panel A: Bank performance variables } \\
\hline OROA & 0.0228 & 0.0199 & 0.0247 & -0.0444 & 0.1435 & 150 \\
\hline ROA & 0.0182 & 0.0160 & 0.0203 & -0.0457 & 0.1133 & 150 \\
\hline \multicolumn{7}{|c|}{ Panel B: Board structure variables } \\
\hline BS & 8.14 & 9 & 2.4248 & 3 & 14 & 150 \\
\hline $\mathrm{BC}$ & 0.8278 & 0.8888 & 0.1460 & 0.25 & 0.9286 & 150 \\
\hline \multicolumn{7}{|l|}{ Panel C: Control variables } \\
\hline TA (In billion Turkish Lira) & 32.021 & 4.684 & 48.743 & 50 & 201.075 & 150 \\
\hline $\mathrm{CR}$ & 0.0546 & 0.0354 & 0.1067 & 0 & 1.1559 & 140 \\
\hline LR & -0.0781 & -0.0469 & 0.2116 & -0.7158 & 0.4512 & 150 \\
\hline NIM & 0.0544 & 0.0479 & 0.0339 & 0.0085 & 0.2659 & 150 \\
\hline NII & 0.0184 & 0.0167 & 0.0227 & -0.0341 & 0.1670 & 150 \\
\hline
\end{tabular}

\subsection{Pearson Correlation Coefficients Matrix between Variables}

Table 3 provides the matrix of Pearson correlation coefficients and variance inflation factors (VIFs) of the variables. As seen in Table 3, it is clear that the dependent variables i.e. OROA and ROA are associated with each other. Both measures of bank performance are found to be negatively and significantly correlated with BS. While the correlation coefficient between OROA and BC is observed to be negative and statistically significant, the correlation coefficient between ROA and $\mathrm{BC}$ is negative but statistically insignificant. The correlation analysis indicates positive and statistically significant correlations between both the two performance measures and NIM and NII. BC is significantly positively correlated with BS. The fact that BS is significantly positively correlated with Ln (TA) may indicate that larger banks have larger boards. BC is significantly positively correlated with the variable Ln (TA). This may show that bigger banks also tend to have more outside board members on their boards. However, high correlation coefficients may give rise to multicollinearity problem among explanatory variables. We therefore employ the VIF as an indicator of multicollinearity. The VIF values for all explanatory variables range from 1.11 to 2.73 , which are well below the acceptable upper limit of 10 , indicating that all independent variables can be used in the same empirical model at the same time (Guajarati, 2004). 
Table 3. Correlation matrix

\begin{tabular}{|c|c|c|c|c|c|c|c|c|c|c|}
\hline Variables & 1 & 2 & 3 & 4 & 5 & 6 & 7 & 8 & 9 & VIFs \\
\hline (1) OROA & 1 & & & & & & & & & - \\
\hline (2) $\mathrm{ROA}$ & 0.99 & 1 & & & & & & & & - \\
\hline (3) $\mathrm{BS}$ & -0.22 & -0.20 & 1 & & & & & & & 2.73 \\
\hline (4) $\mathrm{BC}$ & -0.18 & -0.16 & 0.74 & 1 & & & & & & 2.66 \\
\hline (5) $\operatorname{Ln}(\mathrm{TA})$ & -0.12 & -0.11 & 0.59 & 0.50 & 1 & & & & & 1.68 \\
\hline (6) $\mathrm{CR}$ & 0.15 & 0.14 & -0.21 & -0.23 & -0.267 & 1 & & & & 1.11 \\
\hline (7) LR & -0.15 & -0.14 & 0.09 & -0.13 & -0.012 & 0.11 & 1 & & & 1.15 \\
\hline (8) NIM & 0.55 & 0.54 & -0.32 & -0.18 & -0.370 & 0.18 & 0.04 & 1 & & 1.22 \\
\hline (9) NII & 0.44 & 0.43 & 0.01 & 0.09 & -0.04 & 0.02 & -0.17 & -0.14 & 1 & 1.18 \\
\hline
\end{tabular}

Note. Correlation coefficients significant at the $5 \%$ level or better are in bold. See Table 1 for variable definitions.

\subsection{Regression Results}

In this section we report estimation results of Eq. (1) in Table 4. We use OROA in column 1 of Table 4 and ROA in column 2 of Table 4 as performance measures. We perform Hausman specification test to choose between the random effect and fixed effect methods. As reported in Table 4, we reject the null hypothesis of no correlation between regressors and individual effects. Consequently fixed effect (within) estimator is preferred over random effect estimator and Eq. (1) is estimated by fixed effect estimator.

As reported in column 1 and column 2 of Table 4, the estimated coefficient of board size (BS) is positive and significant at the 5\% level, which is consistent with the conclusions of earlier banking studies (e.g., Belkhir, 2009; Adams \& Mehran, 2012). As anticipated, the positive association between board size and bank performance allows us to accept hypothesis 1 that board size is positively correlated with bank performance. This result also supports for the position of resource dependence theorists.

With respect to the proportion of outside directors on the bank boards, we find that there is a statistically insignificant relationship between the proportion of the outside directors and bank performance, which is also in line with several previous non-banking and banking studies of Hermalin and Weisbach (1991), Bhagat and Black (2001) and Kaymak and Bektas (2008) who, assert that outside directors do not contribute to better performance. Thus, this result is in support of the hypothesis 2 that the proportion of the outside board members is uncorrelated with bank performance. Result of empirical study also fails to support both agency and resource dependence theorists.

Banks' total assets (Ln (TA)) do not have any significant influence on performance of Turkish banks. The possible explanation for this result is that financial performance of Turkish commercial banks does not appear to be affected by their scale in our study.

The negative and statistically significant parameter estimates for credit risk (CR) and liquidity risk (LR) show that banks with higher credit and liquidity risk perform worse. In other words, a negative relationship between risk indicators and performance measures suggests that there is a detrimental influence of risk measures on banks' financial performance.

Net interest income (NIM) has a positive and significant effect on banks' financial performance. This shows that better management of bank asset and liability positively affects banks' returns. Non-interest income (NII) is also found to be positively associated with bank performance as expected, but the coefficient of this variable is not statistically significant. The fact that there is no significant relationship between non-interest income (NII) and bank performance implies that banks do not make use of diversifying their activities beyond the traditional lending activities in Turkey.

In order to check further the robustness of our models, we re-estimate Eq. (1) using Ln (BS) instead of board size (BS). With regard to the sign and the significance of values of all the variables, the unreported results are almost identical to those presented in Table 4 and are available upon request. 
Table 4. Panel fixed effects regression results

\begin{tabular}{ccc}
\hline Independent variables & $(\mathbf{1})$ & $(\mathbf{2})$ \\
\hline \multirow{2}{*}{ Constant } & -0.0502 & -0.0473 \\
& $(0.0772)$ & $(0.0656)$ \\
BS & $0.0060^{* *}$ & $0.0045^{* *}$ \\
& $(0.0023)$ & $(0.0019)$ \\
BC & -0.0634 & -0.0478 \\
& $(0.0935)$ & $(0.0781)$ \\
Ln(TA) & 0.0023 & 0.0022 \\
& $(0.0057)$ & $(0.0046)$ \\
CR & $-0.1238^{* * *}$ & $-0.1047 * * *$ \\
& $(0.0428)$ & $(0.0326)$ \\
LR & $-0.0181^{*}$ & -0.0142 \\
& $(0.0097)$ & $(0.0091)$ \\
NIM & $0.9968^{* * *}$ & $0.8668^{* * *}$ \\
& $(0.2280)$ & $(0.1908)$ \\
NII & 0.0544 & 0.0552 \\
Bank fixed-effects & $(0.0955)$ & $(0.0831)$ \\
Year dummies & Included & Included \\
Sample size & 112 & 112 \\
Number of banks & 28 & 28 \\
F-Statistics & $20.01 * * *$ & $21.46 * * *$ \\
Within R-Squared & 0.5935 & 0.5777 \\
Hausman & $29.47 * * *$ & $30.96 * * *$ \\
\hline
\end{tabular}

Notes. This table presents the results of fixed-effects regressions with bank and year fixed effects. OROA (ROA), performance measure, is used in column 1 (2) of Table 4 and measured by the pre-tax operating income over total assets (the net income over total assets). See Table 1 for a description of the rest of the variables. Heteroskedasticity-consistent asymptotic standard errors are in parentheses. All independent variables are lagged by one year. Year dummies are included but not reported. Significant results at $1 \%, 5 \%$, and $10 \%$ level are marked with $(* * *),(* *),(*)$.

\section{Conclusions}

This paper examines whether size and composition of the board of directors are associated with performance of Turkish commercial banks. Our database consists of unbalanced panel data set of all commercial banks operating in the Turkish banking sector for the period of 2008-2012. Using panel fixed effects regression models, we find a significant and positive relationship between board size and bank performance. Specifically, this empirical result confirms that banks may improve their performance by increasing their board size. We also find that the percentage of outside directors on the board is negatively but insignificantly associated with bank performance. One possible reason for this result is that outside directors appointed to the board may lack specific knowledge regarding the banks and banking sector in Turkey. This study contributes empirical evidence to the little studied area of corporate governance matters in commercial banks in Turkey, an emerging market. Future research can include a larger sample size and a wider period of time different. Board structure variables such as diversity of board members (e.g., gender, age, and nationality), CEO-duality, board member ownership etc. can be used to investigate the relationship between board structure and financial performance and influence of board structure variables on financial performance can be analyzed in deeper form for Turkish commercial banks. The results can be discussed in terms of theory and previous banking and non-banking studies.

\section{References}

Adams, R. B., \& Mehran, H. (2012). Bank Board Structure and Performance: Evidence for Large Bank Holding $\begin{array}{lllll}\text { Companies. Journal of } & \text { Financial Intermediation, 243-267. }\end{array}$ http://dx.doi.org/10.1016/j.jfi.2011.09.002

Agrawal, A., \& Knoeber, C. R. (1996). Firm Value and Mechanisms to Control Agency Problems between Managers and Shareholders. Journal of Financial and Quantitative Analysis, 31, 377-397. Retrieved from http://www.jstor.org/stable/2331397

Agoraki, M. E., Delis, M. D., \& Staikouras, P. (2009). The Effect of Board Size and Composition on Bank Efficiency. MPRA Paper. Retrieved from http://mpra.ub.uni-muenchen.de/18548/ 
Andres, P., \& Vallelado, E. (2008). Corporate Governance in Banking: The Role of the Board of Directors. Journal of Banking \& Finance, 32, 2570-2580. http://dx.doi.org/10.1016/j.jbankfin.2008.05.008

Aygün, M., Taşdemir, A., \& ve Çavdar, E. (2010). Banka Performansı Üzerinde Yönetim Kurulu Büyüklüğünün Etkisi. Atatürk Üniversitesi İktisadi ve İdari Bilimler Dergisi, 24(3).

Baysinger, B. D., \& Butler, H. N. (1985). Corporate Governance and the Board of Directors: Performance Effects of Changes in Board Composition. Journal of Law, Economics, \& Organization, 1(1), 101-124.

Bektas, E., \& Kaymak, T. (2009). Governance Mechanisms and Ownership in an Emerging Market: The Case of Turkish Banks. Emerging Markets Finance \& Trade, 45(6), 20-32. http://dx.doi.org/10.2753/REE1540-496X450602

Belkhir, M. (2009). 'Board of Directors' Size and Performance in the Banking Industry. International Journal of Managerial Finance, 5(2), 201-221. http://dx.doi.org/10.1108/17439130910947903

Bhagat, S., \& Black, B. (1999). The Uncertain Relationship between Board Composition and Firm Value. Business Lawyer, 54, 921-963.

Bhagat, S., \& Black, B. (2002). The Non-Correlation between Board Independence and Long Term Firm Performance. Journal of Corporation Law, 27, 231-274.

Boone, A., Field, L., Karpoff, J., \& Raheja, C. (2008). The Determinants of Corporate Board Size and Composition: An Empirical Analysis. Journal of Financial Economics, 85(1), 66-101. http://dx.doi.org/10.1016/j.jfineco.2006.05.004

Borokhovich, K. A., Parrino, R., \& Trapani, T. (1996). Outside Directors and CEO Selection. Journal of Financial and Quantitative Analysis, 31(3). http://dx.doi.org/ 10.2307/2331395

Choi, S., \& Hasan, I. (2005). Ownership, Governance, and Bank Performance: Korean Experience. Financial Markets, Institutions \& Instruments, 14(4), 215-242. http://dx.doi.org/10.1111/j.0963-8008.2005.00104.x

Coles, J. L., Naveen D. D., \& Lalitha, N. (2008). Boards: Does One Size Fit All? Journal of Financial Economics, 87, 329-356. http://dx.doi.org/10.1016/j.jfineco.2006.08.008

Cornett, M. M., McNutt, J. J., \& Tehranian, H. (2009). Corporate Governance and Earnings Management at Large U. S. Bank Holding Companies. Journal of Corporate Finance, 15, 412-430. http://dx.doi.org/10.1016/j.jcorpfin.2009.04.003

Dalton, D. R., Daily, C. M., Johnson, J. L., \& Ellstrand, A. E. (1999). Number of Directors and Financial Performance: A Meta-Analysis. Academy of Management Journal, 42(6), 674-686. Retrieved from http://www.jstor.org/stable/256988

Doğan, M., \& Ve Yıldız, F. (2013). The Impact of the Board of Directors' Size on the Bank's Performance: Evidence from Turkey. European Journal of Business and Management, 5(6), 130-140.

Fama, E. F. (1980) Agency problems and the theory of the firm. Journal of Political Economy, 88, 288-307. http://dx.doi.org/10.1086/260866

Fama, E. F., \& Jensen, M. (1983). Separation of ownership and control. Journal of Law and Economics, 26, 301-325. http://www.jstor.org/stable/725104

Gill, A., \& Mathur, N. (2011). The Impact of Board Size, CEO Duality, and Corporate Liquidity on the Profitability of Canadian Service Firms. Journal of Applied Finance \& Banking, 1(3), 83-95.

Guest, P. M. (2009). The impact of board size on firm performance: Evidence from the UK. The European Journal of Finance, 15(4), 385-404. http://dx.doi.org/10.1080/13518470802466121

Gujarati, D. N. (2004). Basic Econometrics (4th ed.). The McGraw-Hill Companies, Avenue of the Americas, New York.

Goodstein, J., Gautam, K., \& Boeker, W. (1994). The Effect of Board Size and Diversity on Strategic Change. Strategic Management Journal, 15, 241-250. Retrieved from http://www.jstor.org/stable/2486969

Hermalin, B., \& Weisbach, M. (1991). The effects of board composition and direct incentives in firm performance. Financial Management, 20, 101-112. Retrieved from http://www.jstor.org/stable/3665716

Hermalin, B., \& Weisbach, M. (2003). Boards of Directors as an Endogenously-Determined Institution: A Survey of the Economic Literature. Economic Policy Review, 9, 7-26.

Jensen, M. C. (1993). The Modern Industrial Revolution, Exit, and the Failure of Internal Control Systems. 
Journal of Finance, 48, 831-880. http://dx.doi.org/10.1111/j.1540-6261.1993.tb04022.x

Kaymak, T., \& Bektas, E. (2008). East Meets West? Board Characteristics in an Emerging Market: Evidence from Turkish Banks. Corporate Governance, 16(6), 550-561. http://dx.doi.org/10.1111/j.1467-8683.2008.00713.x

Lehn, K., Sukesh, P., \& Mengxin, Z. (2009). Determinants of The Size and Structure of Corporate Boards: 1935-2000. Financial Management, 38(4), 747-780.http://dx.doi.org/ 10.1111/j.1755-053X.2009.01055.x

Liang, Q., Xu, P., \& Jiraporn, P. (2013). Board characteristics and Chinese bank performance. Journal of Banking \& Finance, 37(8), 2953-2968. http://dx.doi.org/10.1016/j.jbankfin.2013.04.018

Linck, J. S., Netter, J. M., \& Yang, T. (2008). The Determinants of Board Structure. Journal of Financial Economics, 87, 308-328. http://dx.doi.org/10.1016/j.jfineco.2007.03.004

Lipton, M., \& Lorsch, J. (1992). A Modest Proposal for Improved Corporate Governance. Business Lawyer, 48, 59-77. Retrieved from http://www.jstor.org/stable/40687360

Mak, Y. T., \& Kusnadi, Y. (2005). Size Really Matters: Further Evidence on The Negative Relationship Between Board Size and Firm Value. Pacific-Basin Finance Journal, 13, 301-318. http://dx.doi.org/10.1016/j.pacfin.2004.09.002

Macey, J. R., \& O'Hara, M. (2003). The Corporate Governance of Banks. FRBNY (Federal Reserve Bank of New York) Economic Policy Review, 9(1), 91-107.

Nicholson, G. J., \& Kiel, G. C. (2007). Can directors impact performance? A case-based test of three theories of corporate governance. Corp. Gov., 15(4), 585-608. http://dx.doi.org/10.1111/j.1467-8683.2007.00590.x

Nguyen, T., Locke, S., \& Reddy, K. (2014). A dynamic estimation of governance structures and financial performance for Singaporean companies. Economic Modelling, 40, 1-11. http://dx.doi.org/10.1016/j.econmod.2014.03.013

O'Connell, V., \& Cramer, N. (2010). The relationship between firm performance and board characteristics in Ireland. European Management Journal, 28(5), 387-399. http://dx.doi.org/10.1016/j.emj.2009.11.002

Pathan, S., Skully, M., \& Wickramanayake, J. (2007). Board Size, Independence and Performance: An Analysis of Thai Banks. Asia-Pacific Financial Markets, 14(3), 211-227. http://dx.doi.org/10.1007/s10690-007-9060-y

Pathan, S., \& Faff, R. (2013). Does Board Structure in Banks Really Affect Their Performance? Journal of Banking \& Finance, 37, 1573-1589. http://dx.doi.org/10.1016/j.jbankfin.2012.12.016

Panagiotis, K. S., Christos, K. S., \& Agoraki, M. K. (2007). The Effect of Board Size and Composition on European Bank Performance. Eur J Law Econ, 23, 1-27. http://dx.doi.org/10.1007/s10657-007-9001-2

Pfeffer, J. \& Salancik, G. R. (1978). The External Control of Organizations: A Resource Dependence Perspective. New York: Harper \& Row.

Ruigrok, W., Peck, S., \& Keller, P. (2006). Board Characteristics and Involvement in Strategic Decision Making: Evidence From Swiss Companies. Journal of Management Studies, 43(5), 1201-1226. http://dx.doi.org/10.1111/j.1467-6486.2006.00634.x

Saunders, A., \& Cornett, M. M. (2006). Financial Institutions Management: A Risk Management Approach. Boston: McGraw-Hill.

Schellenger, M., Wood, D., \& Tashakori, A. (1989). Board of Directors Composition, Shareholder Wealth and Dividend Policy. Journal of Management, 15, 457-467. http://dx.doi.org/ 10.1177/014920638901500308

Simpson, W. G., \& Gleason, A. E. (1999). Board Structure, Ownership and Financial Distress in Banking Firms. $\begin{array}{lllll}\text { International Review of Economics and } & \text { Finance, }\end{array}$ http://dx.doi.org/10.1016/S1059-0560(99)00026-X

Tanna, S., Pasiouras, F., \& Nnadi, M. (2011). The effect of board size and composition on the efficiency of UK banks. International Journal of the Economics of Business, 18(3), 441-462. http://dx.doi.org/10.1080/13571516.2011.618617

Van der Walt, N., \& Ingley, C. (2003). Board Dynamics and the Influence of Professional Background, Gender and Ethnic Diversity of Directors. Corporate Governance: An International Review, 11, 218-234. http://dx.doi.org/ 10.1111/1467-8683.00320 
Yermack, D. (1996). Higher Market Valuation of Companies with a Small Board of Directors. Journal of Financial Economics, 40(2), 185-211. http://dx.doi.org/ 10.1016/0304-405X(95)00844-5

\section{Notes}

Note 1. Market-based measures of performance are not available because only 12 out of 30 banks are listed on Borsa Istanbul (BIST).

Note 2. Following Saunders and Cornett (2006), the measure of liquidity risk is generated by computing financial gap of commercial banks.

\section{Copyrights}

Copyright for this article is retained by the author(s), with first publication rights granted to the journal.

This is an open-access article distributed under the terms and conditions of the Creative Commons Attribution license (http://creativecommons.org/licenses/by/3.0/). 